\title{
MEŽA PLATĪBU DINAMIKA LATVIJAS AUSTRUMU PIEROBEŽĀ (1967-2015)
}

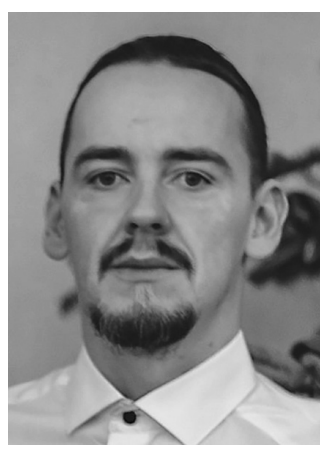

Zigmārs Rendenieks ir ǵeogrāfs, ieguvis doktora grādu Latvijas Universitātes G̣eogrāfijas un Zemes zinātņu fakultātē (2015). Strādā par pēcdoktorantūras pētnieku un pēta zemes lietojuma izmaiņas Latvijā, izmantojot tālizpētes datus. Latvijas G̣eogrāifjas biedrības biedrs kopš 2013. gada.
Raksturvārdi: tālizpēte, zemes segums, lauksaimniecības zemes, meži, apmežošanās.

\section{Latvijas lauku ainavu izmaiṇas pēdējo 50 gadu laikā un izpēte}

Latvijas lauku ainava un meži 20. gadsimtā piedzīvojuši daudzas izmaiņas un satricinājumus. Postījumi divos pasaules karos, iedzīvotāju izsūtišanas un piespiedu kolektivizācija spēcīgi ietekmēja Latvijas laukus, veicinot apsaimniekoto lauksaimniecības zemju pamešanu. Visuzskatāmākās sekas šim procesam ir pamesto zemju apmežošanās, kas Latvijas meža kopējo platību pēdējo 90 gadu laikā gandrīz dubultojusi' ${ }^{1}$ Šis process turpinās arī mūsdienās.

Noritot vairākiem kolhozu un padomju saimniecību apvienošanas viḷniem 60 . un 70. gados, notika nomaļāko zemju un apdzīvoto vietu pamešana, izveidojot jaunus apdzīvojuma centrus un koncentrējot lauksaimnieciskās ražošanas pūlininus uz tām zemēm, kuras varēja efektīvāk apstrādāt mehanizēti un kurās bija iespējama plaša mēroga zemju nosusināšana (līdzenumi ar piemērotu augsni un pietiekoši attīstītu ceḷu tīklu). Šajā laikā notika lielas pārmainas zemes lietojuma veidu telpiskajā struktūrā - apvienojot laukus, tika veidoti lieli tīrumu masīvi, tika apartas ganības un notika plaša mēroga meliorācijas projekti. Lauksaimnieciskās platības uz pauguriem, mežu ielokos vai tālu no celiem bieži tika pamestas, koncentrējoties uz līdzenumiem² ${ }^{2}$ Tā rezultātā marginalizētās zemes gadu desmitu laikā apauga ar krūmiem un kokiem, ḷajot meža platībām palielināties, līdz tās sasniedza $52,1 \%$ no sauszemes platības.

Latgale ir vēsturiski mazāk mežainais Latvijas apgabals, kurā dominējušas lauksaimniecībā izmantojamās zemes - 1923. gadā šeit mežs klāja tikai aptuveni $15 \%$ sauszemes. Pēc Otrā pasaules kara šeit tika radikāli izmainīta tradicionālā ciemu (sādžu) apdzīvojuma struktūra, un mežaino platîbu îpatsvars, kaut izteikti palielinājies, joprojām ir zemāks nekā citos Latvijas vēsturiskajos apgabalos.

1 Meža apsaimniekošana 2019.

2 Boruks 2003. 
Ir daudz pētījumu par zemes seguma un ainavu izmaiṇām pēc Padomju Savienības sabrukuma. Tie pievēršas gan zemes seguma izmaiņu procesiem un to sekām ${ }^{3,4}$, gan šos procesus virzošajiem spēkiem 5 . Šādi pētījumi visbiežāk pamatojas uz datiem, kas iegūti, analizējot satelītattēlus ar precīziem automātiskās klasifikācijas algoritmiem. Tomēr ir maz tādu pētījumu, kuri analizē ainavu izmaiņas padomju periodā, izmantojot telpiskos datus. Šāds trūkums galvenokārt ir skaidrojams ar precīzu, telpiski piesaistītu datu trūkumu. Padomju laikā publicētās kartes šim nolūkam neder, jo tajās ir sastopami apzināti sagrozījumi, turklāt tās ir kartogrāfiski ǵeneralizēti produkti. Latvijā veiktie pētījumi ${ }^{6,7}$ pārsvarā ir balstîti uz statistikas datu analīzi un vēsturisko karšu kā datu avota izmantošanu.

Šì pētījuma mērkis bija kartēt un analizēt meža platību dinamiku Latvijas austrumu pierobežā no 1967. gada līdz 2015. gadam. Jaunu un daudzsološu datu izmantošana un inovatīvas apstrādes un analīzes metodes šim pētījumam piešksir papildu aktualitāti.

\section{Jaunas metodes un dati meža platības dinamikas kartēšanā}

Veicot kvantitatīvus pētījumus par zemes seguma izmaiņām Latvijā padomju laikā, ierobežojums ir augstas izšķirtspējas datu pieejamība. Slepenības dēḷ Padomju Savienībā precīzas kartes, nemaz nerunājot par augstas izšķirtspējas satelītattēliem, nebija pieejamas. Tomēr kopš 1996. gada ir pieejami ASV satelìtattēli no Corona misijas. Corona (sākotnējais nosaukums - Discoverer) bija amerikāņu militārās izlūkošanas fotogrāfisko satelītu paaudze, kuras ietvaros laika posmā no 1961 . līdz 1972. gadam 95 veiksmīgās misijās tika iegūti simtiem tūkstošu attēlu, kas pārklāja visu pasauli, bet galvenokārt aukstā kara pretinieku nometni - PSRS un Ķīnu. Šie attēli tika uzņemti uz melnbaltas filmas, kuras rulli i kapsulās tika nomesti no orbītas un notverti

\footnotetext{
3 Kuemmerle et al. 2011.

4 Potapov et al. 2015.

van Vliet et al. 2015.

Penēze 2009.

7 Fescenko et al. 2014.
}

kritienā ar speciāli aprīkotu lidmašinu. Šis process prasīja augstu pilotu meistarību un arī veiksmi. Attēlu izškirirtspēja vēlākajos kameru model̦os (KH-4A un KH-4B) sasniedza 2,5 m ${ }^{8}$. Šie attēli no 1967. gada izmantoti šajā pētījumā.

Situācijas raksturošanai pētījuma teritorijā (1. att.) izmantoti arī Landsat programmas satelītattēli - Landsat 5 (1989) un Landsat 8 (2015). Corona attēliem tika veikta fotogrammetriskā apstrāde un izveidota ortofoto mozaīka ar 2,5 m izšķirtspēju. Landsat attēliem veikta atmosfēriskā korekcija un izveidotas mozaīkas ar 30 m izšķirtspēju (1989 un 2015). Izmantoto izejas datu dažādības un arī attēla trokšnu līmeņa dēḷ Corona attēlos meža platību kartēšanā tika izmantota attēlu segmentācijas pieeja, kas izpaužas kā objektu izdalīšana attēlos pretstatā atsevišḳu attēla šūnu (pikseḷu) klasifikācijai. Tālākajos soḷos izdalītie objekti tika klasificēti meža un nemeža objektos, izmantojot spektrālos un tekstūras rādītājus. Šādi tika samazināta kḷūdaini klasificēto objektu proporcija - meža platību dinamikas kartēs klasifikācijas precizitāte sasniedza 90 un $93 \%$.

Tika iegūtas kartes, kurās attēlotas meža platības (2. att.), un no tām izveidotas divas izmainu kartes - pa vienai katram pētījuma periodam (1967-1989 un 1989-2015). Šajās kartēs katra laika posma ietvaros visa pētījuma teritorija iedalīta četrās klasēs: 1) stabils mežs (meža segums bez izmain̄ām), 2) stabils nemežs (nemeža segums bez izmaināam), 3) meža platību pieaugums un 4) meža platību zudums. Šādi iespējams attēlot un arī skaitliski raksturot meža platību dinamiku vienā kartē. Šo kategoriju platības tika precizētas, izmantojot klasifikācijas kḷūdu matricu.

Lai novērtētu izmaiņas meža teritoriju ainavu ekoloǵiskajā struktūrā, tika aprēḳināti meža teritoriju telpiskā raksta indikatori. Morfologiiskā telpiskā raksta analīze (MSPA) iedala ainavas struktūrelementus septiņās klasēs pēc to funkcionēšanas: kodolzonas, plankumi, cilpas, koridori, robi, malas un atzari. Šo elementu platîbas tiek izteiktas skaitliski, l,aujot novērtēt ainavas telpiskās struktūras izmaiņas noteiktā laika posmā.

8 Grosse et al. 2005 


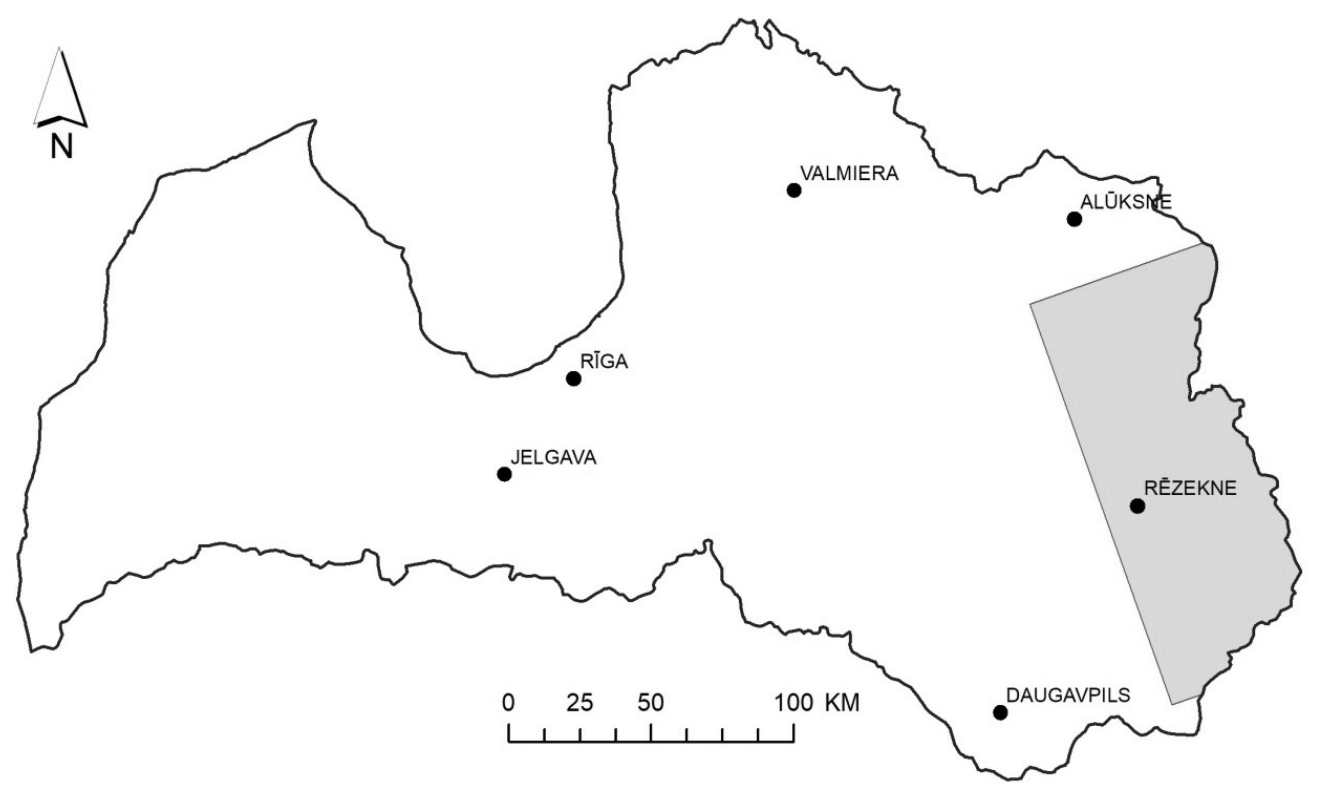

1. attēls. Pētijuma teritorija

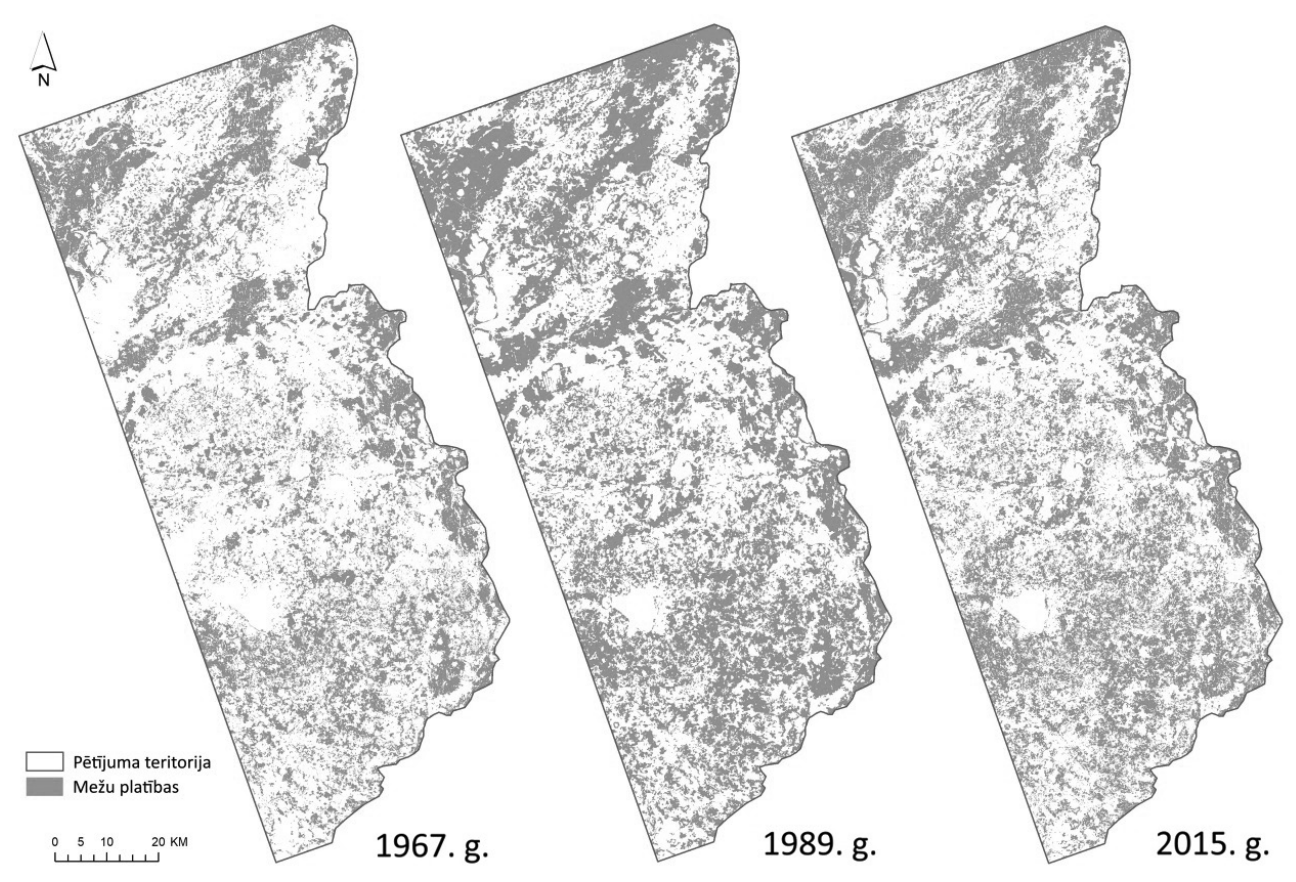

2. attēls. Meža platības pētījuma teritorijā 1967., 1989. un 2015. gadā 
Tabula. Precizētās meža platību izmaiṇas pētījuma teritorijā 1967.-1989. un 1989.-2015. gadā

\begin{tabular}{lcccc}
\hline \multicolumn{1}{c}{$\mathbf{1 9 6 7 - 1 9 8 9}$} & Platība (1000 ha) & SE & Proporcija (\%) & SE \\
\hline Stabils mežs* & 195,5 & 16,6 & $25,0 \%$ & $2,1 \%$ \\
Stabils nemežs & 388,1 & 29,9 & $49,6 \%$ & $3,8 \%$ \\
Meža pl. pieaugums & 157,8 & 18,7 & $20,1 \%$ & $2,4 \%$ \\
Meža pl. zudums & 41,8 & 6,6 & $5,3 \%$ & $0,8 \%$ \\
1989-2015 & & & & \\
\hline Stabils mežs & 251,7 & 17,2 & $32,1 \%$ & $2,2 \%$ \\
Stabils nemežs & 379,2 & 22,2 & $48,4 \%$ & $2,8 \%$ \\
Meža pl. pieaugums & 56,3 & 5,9 & $7,2 \%$ & $0,8 \%$ \\
Meža pl. zudums & 96,1 & 10,1 & $12,3 \%$ & $1,3 \%$ \\
\hline
\end{tabular}

* Stabils mežs - teritorija, kurā pētāmajā periodā bijis meža segums. SE - standartkḷūda.

\section{Meža platību dinamika un konstatēto izmainu sekas}

Pētījuma rezultāti arī parādīja, ka pēdējā pusgadsimta laikā meža platības pieaugušas galvenokārt padomju periodā (1967-1989). Sākot ar 1967. gadu, kad pieejami senākie satelītuznēmumi, kas pārsedz visu pētījuma teritoriju, meža platības pieaugušas par $20,1 \%$. Sekojošajā laika posmā pēc neatkarības atgūšanas (1989-2015) meža platîbu pieaugums bija daudz zemāks - 7,2\%. Teritorijas, kurās meža segums izzudis, veido 5,3\% (1967-1989) un 12,3\% (1989-2015) no pētījuma teritorijas kopējās platības (tabula).

Protams, šajā pētījumā konstatētās izmainas raksturo Latvijas austrumu pierobežas regiionu un stipri izteiktas reǵionālas atšķirības meža platību dinamikā Latvijā kopumā liedz šos secinājumus vispārināt. Pētījumā par Latvijas lauku ainavu izmaiņām 20. $\operatorname{gadsimtā}{ }^{9}$ noskaidrots, ka 1929.-2001. gadā meža platības visvairāk pieaugušas Vidzemes, Idumejas, Augšzemes un Latgales augstienē, kā arī Mudavas zemienē, vismazāk - Zemgales līdzenumā.

Šāds meža platību pieaugums dažu gadu desmitu laikā ir ietekmējis arī šo teritoriju vizuālo veidolu un ainavu ekoloǵisko struktūru. Pētījumā konstatētais kodolzonu platību pieaugums, kā arī atsevišksu plankumu un koridoru proporcijas samazināšanās (3. attēls) norāda uz meža teritoriju defragmentāciju, kas notiek,

9 Penēze 2009. saslēdzoties meža masīviem un mazākiem meža puduriem. Īpaši izteikts šis process ir bijis mozaīkveida ainavās Latgales augstienē. Papildus šiem procesiem otrajā pētījuma periodā - no 1989. līdz 2015. gadam - izteikti pieauga mežizstrādes intensitāte, kas pārsvarā notikusi valsts mežos, t. i., lielajos meža masīvos. Tādējādi abi procesi - gan dabiskā apmežošanās, gan intensīva mežizstrāde - notiek paralēli dažādās teritorijās.

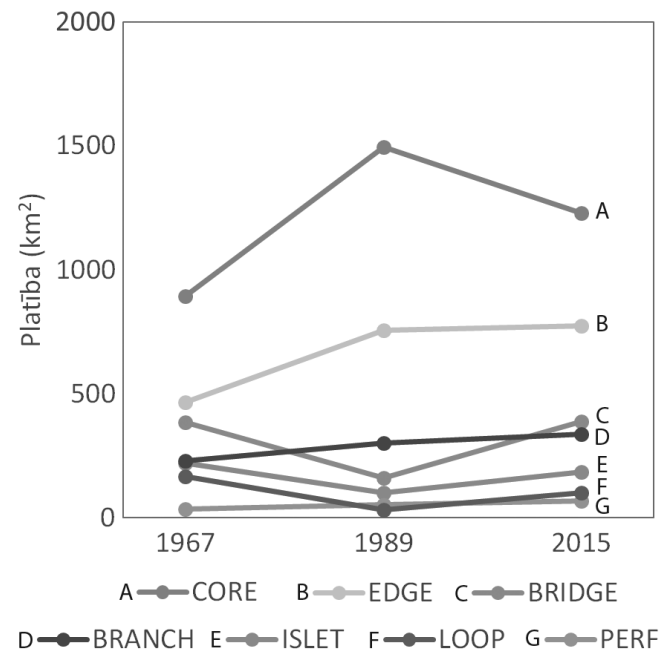

3. attēls. Ainavu ekoloğiskās struktūras elementu platību izmaiṇas pētījuma periodā (CORE - kodolzonas, ISLET - plankumi, PERF - robi, EDGE - malas, LOOP - cilpas, BRIDGE - koridori, BRANCH - atzari) 
Jautājums, vai ES maksājumi, kas Latvijas zemniekiem ir pieejami kopš 2004. gada, ir būtiski ietekmējuši zemju pamešanas tempus, joprojām nav pilnībā atbildēts. Oḷǵerts Nikodemus u. c., pētot Latvijas centrālo dalı ${ }^{10}$, secinājuši, ka ES platību maksājumiem ir bijis ierobežots efekts uz lauksaimniecības zemju pamešanas tempu, bet mazāk izteikts tas bijis marginālajās teritorijās ar augstu zemju pamešanas risku.

Latvijas mežu ilgtspējīgā apsaimniekošanā nākotnē svarīgi būs pieņemtie lēmumi par jauno meža zemju - to meža platību, kuras izveidojušās pēdējo 50 gadu laikā, - apsaimniekošanu. Tā kā aptuveni $75 \%$ šo jauno meža zemju pieder privātajiem īpašniekiem, pieaugoša nozīme nākotnē būs meža īpašnieku kooperācijai un meža īpašumu konsolidācijai, kas l̦aus efektīvāk apsaimniekot šobrīd sadrumstalotos meža īpašumus atbilstoši ilgtspējīgas mežsaimniecības principiem.

10 Nikodemus et al. 2007.
Tāpat pagaidām neatbildēts ir jautājums par to, kādas būs ilgtermiņa ekolog̣iskās sekas šādām dramatiskām ainavu pārmain̄ām, kuras norisinājās 20. gs. otrajā pusē. Pētījumā konstatētā meža masīvu saslēgšanās un jaunu puduru izveidošanās, aizaugot aramzemēm un ganībām, izmaina ainavu ekoloǵisko struktūru, kas nevar neietekmēt ekologiskās plūsmas un bioloǵisko daudzveidību Latvijā.

Corona attēlu izmantošana lıuj veidot garākas augstas izškikirtspējas datu laikrindas zemes seguma izmainu pētījumos, un šādi garāku laika posmu pētījumi sniedz pilnīgāku skatîjumu uz ainavu izmaiņu procesiem, virzošajiem spēkiem un šo procesu sekām mūsdienās un nākotnē.

Šis pētījums veikts ar ERAF finansiālu atbalstu pasākuma 1.1.1.2. Pēcdoktorantūras pètniecības atbalsts ietvaros projektā Jauno meža zemju nozīme ainavas telpiskās struktūras izmain̄ās Latvijā no 1967. lìdz 2017. gadam (Nr. 1.1.1.2/VIAA/2/18/277).

\section{VĒRES}

Boruks, A. (2003) Zeme, zemnieks un zemkopība Latvijā. Jelgava : LLU.

Fescenko, A.; Nikodemus, O.; Brūmelis, G. (2014) Past and contemporary changes in forest cover and forest continuity in relation to soils (Southern Latvia). Polish Journal of Ecology, 62, 4, 625-639.

Grosse, G.; Schirrmeister, L.; Kunitsky, V. V.; Hubberten, H. W. (2005) The use of CORONA images in remote sensing of periglacial geomorphology: an illustration from the NE Siberian coast. Permafrost and Periglacial Processes, 16, 2, 163-172.

Kuemmerle, T.; Olofsson, P.; Chaskovskyy, O.; Baumann, M.; Ostapowicz, K.; Woodcock, C. E.; Houghton, R. A.; Hostert, P.; Keeton, W. S.; Radeloff, V. C. (2011) Post-Soviet farmland abandonment, forest recovery, and carbon sequestration in western Ukraine. Global Change Biology, 17, 3, 1335-1349.

Meža apsaimniekošana (2019) Pieejams: http://www.vmd.gov.lv/valsts-meza-dienests/statiskas-lapas/-mezaapsaimniekosana-?nid=1472\#jump (20.07.2019.).

Nikodemus, O.; Bell, S.; Penēze, Z.; Krūze, I. (2010) The influence of European Union single area payments and less favoured area payments on the Latvian landscape. European Countryside, 2, 1, 25-41.

Penēze, Z. (2009) Latvijas lauku ainavas izmaiņas 20. un 21. gadsimtā: cēloṇi, procesi un tendences: Promocijas darbs. Rīga : LU.

Potapov, P. V.; Turubanova, S. A.; Tyukavina, A.; Krylov, A. M.; McCarty, J. L.; Radeloff, V. C.; Hansen, M. C. (2015) Eastern Europe's forest cover dynamics from 1985 to 2012 quantified from the full Landsat archive. Remote Sensing of Environment, 159, 28-43.

van Vliet, J.; de Groot, H. L.; Rietveld, P.; Verburg, P. H. (2015) Manifestations and underlying drivers of agricultural land use change in Europe. Landscape and Urban Planning, 133, 24-36. 